\title{
The Egyptian World in the Time of Tutankhamen.
}

\author{
By Dr. H. R. HALL.
}

$\mathrm{T}^{\mathrm{H}}$ E name of Tutankhamen, king of Egypt, whose reign may with comparative certainty be placed in the decade $x_{360-r} 350$ B.c., is now a household word, and is probably known to many who have never heard of Thothmes or Rameses. The discovery of his tomb at Thebes by Lord Carnarvon and Mr. Howard Carter, with its wealth of funerary furniture and the magnificent state which probably enshrines the actual body of the king, has made Tutankhamen familiar to all ; so that, at any rate for the time, we regard him as the typical Egyptian pharaoh of his age. But, as a matter of fact, he was an ephemeral and undistinguished monarch personally, and his short reign is only remarkable for one fact, the return of Egypt to the polytheistic faith of her forefathers after the short episode of the Disk-worshipping heresy of his father-in-law, Akhenaten, the artist, poet, and pacificist, one of the most extraordinary figures of the ancient world.

Akhenaten is the outstanding figure of his century, but he, again, is not the typical great king of his time : it is his father, Amanhatpe or Amenhotep III., the Memnon of the Greeks, who can rightly claim that position. Akhenaten was too strange and unconventional a figure. Tutankhamen began by following the heresy of his father-in-law, but in his day the reaction came, and the great god Amen of Thebes, king of the gods and head of the imperial pantheon, returned to his own. It is probably on this account that Tutankhamen was buried in the magnificent splendour that we see: Amen- $\mathrm{Ra}$ and his triumphant priests saw to it that the returned prodigal received fitting burial, with all the provision that the old religion could give him to ensure his dignity and well-being in the next world.

It is at the moment of his return to the national religion's fold that we survey the state of the world as known to the Egyptians, for to go further afield would bear us into endless paths of speculation. Egypt and Mesopotamia give us the only known chronological bases for real history at this time ; to go outside their world, into the Bronze Age of Western Europe, for example, would be to cast loose from the control of known dates and events and to speculate merely as to the probable growth of civilisation, not to write history.

What was the world like outside Egypt, as known to the Egyptians, in Tutankhamen's day?

About I580 B.c. the Syrian and Canaanite invaders who had dominated Egypt for at least two centuries, the Hyksos or Shepherd-Kings, had been expelled by force, and the Egyptians, filled with the spirit of revanche, had in their turn imposed their rule on the lands of their oppressors. The raids of the earlier kings of the XVIIIth Dynasty, which now occupied the throne of Thebes, had crystallised under Thutmases, or Thothmes, III. into a settled policy of conquest and empire, and Amenhotep III. was the undisputed ruler of Syria, Palestine, and Phœnicia.

These countries were regarded by the kings of Babylon and Assyria as the rightful domains of the king of Egypt, their peoples as his subjects. He was their lord in peace and war. Egyptian residents and generals controlled the native princes. The Egyptian frontier ran from the Amanus and north of the Aleppan district to the Euphrates near Carchemish, and thence down the river for some distance, till it turned off and ceased in the undefined wastes of the desert, reappearing at the head of the gulf of Akabah, in the land of Edom. The great historical cities of Syria, Aleppo, Carchemish, Damascus, and Jerusalem; the Phœnician cities of the coast from Arvad in the north, past Byblos, of old an Egyptian centre, Tyre, and Sidon to Akko in the south ; the towns of the Philistine coast, from Dor to Gaza; had already existed for centuries. But though the Phœnicians were there, the Philistines were not yet in the land which afterwards bore their name, Palestine. They did not arrive in Canaan till nearly two centuries later.

Outside the Egyptian border to the west, in the days of Amenhotep III., the ancient kingdom of Babylonia existed in august but somewhat faded and inert majesty, as old as Egypt and as proud, but weak and querulous, trusting to the power of old renown as her protection against attack rather than to warlike prowess. Officially she now bore the name of Karduniyash, an appellation given her by the kings of her foreign Kassite dynasty, a race of conquerors, probably of Indo-European origin, who had come from beyond the Zagros some four centuries before.

North of her, on the Tigris, was Assyria, also an ancient power, but younger; Babylonian in culture, but more purely Semitic in race; and rejecting the claim to suzerainty which Babylon sought to impose on her. To the west of Assyria was the ill-defined kingdom of Mitanni, the land of Northern Mesopotamia between the Khabūr, the Euphrates, and the mountains of Diarbekir, inhabited by an intrusive race of uncertain origin ruled by kings probably, like the Kassites, of Aryan origin.

Farther west, beyond Taurus, was the confederation of tribes of the Anatolian Hittites, who owed allegiance to an overlord, the "Sun" of Khatti, reigning in central Anatolia, at a city represented by the modern Boghàz Köi, east of the Halys. The ancient Semitic population of Cappodocia no longer existed, having been destroyed or expelled by the Hittites.

Hittite tribes had already crossed the Taurus, inhabited the districts of Aleppo and Carchemish, and had even pushed outposts down as far south as Palestine, where they lived under Egyptian rule, side by side with the Canaanites and with Aryans from Mitanni.

South of the Anatolian Hittites was Cilicia, inhabited by a kindred race, of whose culture we know little, but that it owed much, probably, both to the Hittite and to the Syrian.

The island of Cyprus, the people of which also were racially related to the Anatolians, probably, had recently been conquered by Ægean tribes from Rhodes and Greece itself, who brought with them the Mycenæan culture, now beginning in Greece to take the place of the Minoan civilisation of Crete from which it was derived. The Minoan civilisation was now eclipsed on account of the collapse of the dominion of Knossos, which had sent ambassadors to Egypt in the days of Thothmes III. 
This was, leaving out of account the Sudan in the south and the wild Libyan tribes to the west, the world as known to the Egyptians. Of Italy, they probably had as yet no knowledge.

Towards the end of the reign of Amenhotep III. a revolution broke out in Syria and Palestine. Shubbiluliuma or Suppilulius, king of the Hittites, a monarch full of guile, aspired to oust Egypt from the control of Syria and to destroy Mitanni. He found tools ready to his hand in certain discontented and rebellious Amorite princes of the Lebanon and in the Phœnicians of Arvad, and stirred up strife. Amenhotep quelled the revolt for a time, but it broke out again, and when his extraordinary son, Akhenaten, ascended the throne, the whole country seethed with turmoil.

The new king was interested only in his project of reforming the Egyptian religion; he was a man of art and of peace, and for the first time in history, perhaps, a great king refused to go forth to war, and allowed his dominions to fall away from him.

Palestine and Syria were in chaos. Wandering tribes, among them those Khabiri who have been credibly identified with the Hebrews, overran the land, the Hittite princes of the south revolted, and with them certain chiefs of Aryan (? Mitannian) origin who also had settled there under the Egyptian dominion. The Canaanite chiefs and Phœnician princes who remained faithful were gradually borne down in the absence of help from Egypt, and at the end of Akhenaten's reign the whole country had fallen away from the king.

In Tutankhamen's day the great prince Huy may represent himself on the walls of his tomb, as he does, bringing Semitic chiefs to offer tribute to his majesty, but we see that this can have been but a farce: the king's writ ran no farther than the coast of the Shephelah, probably. In the north the Amorites had but exchanged one master for another, for they now became the vassals of the Hittites, albeit under a looser control than that of Egypt. The Hittite control of Syria continued unchallenged till the days of Seti I. and Rameses II., fifty years later, when Egypt essayed to reimpose her yoke on the Semites. Long wars ensued, waged directly by Egypt against the Hittites, until about I 279 B.c. a peace of exhaustion was concluded between the protagonists, a peace of which we have the full protocol, signed and sealed by the Great King of Egypt and the Great King of Khatti, couched in diplomatic and legal phraseology that might have issued from a modern chancellery. It was a com- promise : of her old Asiatic dominion Egypt retainec only Palestine ; Syria fell to the Hittites and remained theirs till, eighty years later, the invasion of the Philistines and their seafaring allies from the North overthrew the Hittite kingdom and tore Palestine itself from Egypt.

Tutankhamen, then, was confronted across his attenuated frontier by a far more formidable foe than the Babylonian could ever be. Mitanni was gone-destroyed by Shubbiluliuma after all help from Egypt had proved vain. Assyria, trusting in the prowess of her soldiers, kept her independence of both Babylon and Khatti; Shubbiluliuma seems prudently to have let her be. Her king, Ashur-uballit, was a long-lived and probably a politic as well as a doughty ruler. Somewhat later, in the time of Rameses II., Shalmaneser, king of Assyria, was a much more powerful monarch than the Babylonian Kadashman-turgu, and it was partly in apprehension of his power, probably, that Rameses and Khattusilis, the Hittite ruler, finally compromised their differences.

The collision of different national civilisations at this time produced none of the mutual approximations that might have been expected. Only Egypt began to show signs, more accentuated later, of Semitic influence in her culture. Babylon, however, shows no signs of Egyptian influence, the Hittites perhaps a little, the Mycenæans more. But there is no landslide in any direction anywhere. Each people remained faithful to its traditions. There were colonies of Mycenæan artists, as of Semitic and even Hittite craftsmen in Egypt. But though the Egyptians prized and used Greek products, we find no direct imitation of Minoan art even in the free and untrammelled Egyptian art of Akhenaten's time, though the works of the Minoan artists must have appealed to the realistic and truth-loving king. There is no trace of Minoan or of Mesopotamian influence yet in any of the objects of Egyptian art discovered in Tutankhamen's tomb of which photographs have been published: the weird heads, for example, of one of the gilded couches that have been thought to be Mesopotamian in aspect are merely heads of the Egyptian goddess Thoueris in her fierce and typhonic character. We should, in fact, expect Mesopotamian influence less than Minoan or even Hittite. The Thoueris-head was adapted by the Minoans for the heads of their water-demons.

Such, in brief survey, are the main characteristics of the outer world known to Tutankhamen and his people, and of Egypt's relations with it.

\section{Recent Advances in Photographic Theory. ${ }^{1}$}

By Dr. C. E. K. MeEs.

THE study of the physico-chemical relations 1 on which depend the form in which a precipitate is produced has been developed by a number of workers in recent years, and its application to the precipitation of silver halide has been studied by Sheppard and Trivelli. In his earlier work Trivelli made a large number of photomicrographs of emulsions taken from standard photographic plates and films,

${ }^{1}$ Communication No. 165 from the Research Laboratory of the Eastman Kodak Company. From a lecture delivered before the Franklin Institute of Philadelphia on December 7,1922 . one of which is reproduced in Fig. I. It will be seen that the silver bromide grains, of which the emulsion is composed, are of very varied sizes, there being present a large number of small grains, down to the limit of those visible with a microscope, and a smaller number of large grains, including some of very much greater area than the smallest grains present. The largest grains are all polygons, with angles of $60^{\circ}$ and $\mathrm{I} 20^{\circ}$. There is a tendency to round off the corners and edges of the small grains, so that the smallest grains appear to be more or less spherical. 